DOI: https://doi.org/10.36910/6775-2524-0560-2021-43-21

УДК 621.311

Рощенко Олексій Миколайович, старший науковий співробітник

https://orcid.org/0000-0002-3562-5428

Український науково-дослідний інститут спеціальної техніки та судових

експертиз Служби безпеки України, м. Київ

\title{
ПЕРСПЕКТИВНІ НАПРЯМКИ РОЗШИРЕННЯ ФУНКЦІОНАЛЬНОСТІ ПОРТАТИВНИХ ЕЛЕКТРОННИХ ПРИСТРОЇВ: ЗАРУБІЖНИЙ ДОСВІД
}

\begin{abstract}
Рощенко О. М. Перспективні напрямки розширення функціональності портативних електронних пристроїв: зарубіжний досвід. У статті розкрито зарубіжний досвід напрямків розширення функціональності портативних електронних пристроїв. Визначено слабкі сторони сучасних портативних електронних пристроїв. Зазначено, що переносні електронні пристрої, включаючи мобільні телефони, портативні комп'ютери, планшети та мобільні (переносні) електронні пристрої сприяють швидкому зростанню обробки та обміну інформацією. Підкреслено, що швидкий прогрес портативних електронних пристроїв неможливий без поступового вдосконалення технологій акумуляторних батарей. Первинні батареї вже використовувались як основне джерело енергії портативних електронних пристроїв протягом тривалого періоду. Наведено внутрішні та зовнішні методи захисту батарей портативних електронних пристроїв. Окремо відзначено портативні електронні пристрої, що мають механічну гнучкість (наприклад, зсувні дисплеї), вони представляють новий напрямок для електронної промисловості. Крім того, вони можуть поєднуватися з мобільними датчиками (наприклад, розумним одягом), щоб зробити революцію в житті людини. Наголошено, що електрохімічні функції гнучких батарей зазвичай погіршуються при тривалих частих механічних деформаціях, наприклад, при згинанні, згортанні, скручуванні та інших режимах деформації. 3 високою ємністю, можливістю швидкого заряджання / розряджання та чудовою стабільністю на циклі, що може бути додатково поєднано з гнучкими електролітами та сепараторами. Зазначається, що 3 метою подальшого задоволення постійно високих вимог до акумуляторних батарей у портативних електронних пристроїв, значні зусилля у галузі досліджень у всьому світі були спрямовані на вдосконалення існуючих акумуляторних систем з використанням нових матеріалів, передових технологій та нових енергетичних хімічних сполук.
\end{abstract}

Ключові слова: портативність, електронний пристрій, функціональність, розширення, батарея, заряд.

Рощенко А. Н. Перспективные направления расширения функциональности портативных электронных устройств: зарубежный опыт. В статье раскрыто зарубежный опыт направлений расширения функциональности портативных электронных устройств. Определены слабые стороны современных портативных электронных устройств. Отмечено, что переносные электронные устройства, включая мобильные телефоны, портативные компьютеры, планшеты и мобильные (переносные) электронные устройства способствуют быстрому росту обработки и обмена информацией. Подчеркнуто, что быстрый прогресс портативных электронных устройств невозможен без постепенного совершенствования технологий аккумуляторных батарей. Первичные батареи уже использовались как основной источник энергии портативных электронных устройств в течение длительного периода. Приведены внутренние и внешние методы защиты батарей портативных электронных устройств. Отдельно отмечено портативные электронные устройства, имеющие механическую гибкость (например, сдвижные дисплее), они представляют новое направление для электронной промышленности. Кроме того, они могут сочетаться с мобильными датчиками (например, умным одеждой), чтобы сделать революцию в жизни человека. Отмечено, что электрохимические функции гибких батарей обычно ухудшаются при длительных частых механических деформациях, например, при сгибании, свертывании, скручивании и других режимах деформации. С высокой емкостью, возможностью быстрой зарядки / разрядки и превосходной стабильностью на цикле, что может быть дополнительно соединяются с гибкими электролитами и сепараторами. Отмечается, что с целью дальнейшего удовлетворения постоянно высоких требований к аккумуляторных батарей в портативных электронных устройств, значительные усилия в области исследований во всем мире были направлены на совершенствование существующих аккумуляторных систем с использованием новых материалов, передовых технологий и новых энергетических химических соединений.

Ключевые слова: портативность, электронное устройство, функциональность, расширение, батарея, заряд.

Roschenko Oleksii. Promising areas for expanding the functionality of portable electronic devices: foreign experience. The article reveals foreign experience in expanding the functionality of portable electronic devices. Weaknesses of modern portable electronic devices have been identified. It is noted that portable electronic devices, including mobile phones, laptops, tablets and mobile (portable) electronic devices contribute to the rapid growth of information processing and exchange. It is emphasized that the rapid progress of portable electronic devices is impossible without the gradual improvement of battery technology. Primary batteries have been used as the main source of power for portable electronic devices for a long time. Internal and external methods of protection of batteries of portable electronic devices are given. Portable electronic devices with mechanical flexibility (for example, sliding displays) are singled out, they represent a new direction for the electronics industry. In addition, they can be combined with mobile sensors (such as smart clothing) to revolutionize human life. It is emphasized that the electrochemical functions of flexible batteries usually deteriorate during prolonged frequent mechanical deformations, such as bending, folding, twisting and other modes of deformation. With high capacity, fast charging / discharging capability and excellent cycle stability, which can be further combined with flexible electrolytes and separators. It is noted that in order to further meet the ever-increasing demands on batteries in portable electronic devices, significant research efforts around the world have focused on improving existing battery systems using new materials, advanced technologies and new energy chemicals.

Key words: portability, electronic device, functionality, expansion, battery, charge. 
Постановка проблеми. Сучасні портативні електронні пристрої (ПЕП) є перспективними платформами для обміну інформацією для реагування в режимі реального часу. Їх показники стають дедалі більш чутливими до споживання енергії. Акумуляторні батареї є основним джерелом енергії ПЕП і містять ключ, щоб гарантувати їх бажану стабільність роботи. Завдяки надзвичайному прогресу в технологіях акумуляторів постійно з'являються багатофункціональні ПЕП, для задоволення запитів повсякденного життя сучасного населення. Постійний сплеск попиту на високоефективні ПЕП надихає на невпинне переслідування ще більш потужних акумуляторних систем. Необхідність розширення функціональності портативних електронних пристроїв є головною вимогою. За останні десятиліття міжнародні організації розробили та впроваджують акумуляторні батареї нового покоління здатні максимально сприяти підвищенню часу дії ПЕП. Вітчизняний ринок на крок позаду, необхідність перейняття зарубіжного досвіду є беззаперечним фактом.

Аналіз останніх досліджень і публікацій. Формування наукової думки з питань розширення функціональних можливостей портативних електронних пристроїв датується 2000 роком, саме тоді портативні пристрої почали активно впроваджуватися в усі сфери життя людини. Чимало науковців здійснили свій вклад у розвиток портативних електронних пристроїв.

А.В. Король, Т.А. Кравцова та О.М. Муравйова [1] дослідили питання застосування мобільних пристроїв у системі навчання. Авторами наведено приклади завдань, які можуть бути вирішені за допомогою застосування цих засобів. Розглянуто основні можливості використання мобільних гаджетів у навчальній діяльності під час візуалізації демонстраційного матеріалу, анкетування, тестування, а також під час дистанційного навчання.

Статтю [2] присвячено дослідженню мобільної комерції в Україні. Проаналізовано переваги мобільної комерції та виокремлено низку проблем, вирішення яких сприятиме розвитку мобільної комерції в Україні.

А.В. Гріччіна [3] розкрила можливості використання мобільних додатків для розвитку іншомовної мовленнєвої компетенції студентів.

Щодо модернізації батарей портативних пристроїв значний внесок здійснила робота В. I. Будько [4]. Автор обгрунтував техніко-економічні параметри при формуванні мереж зарядних станцій електромобілів з буферними акумуляторами енергії при використанні енергії сонячного випромінювання та вітру.

Iз зарубіжних авторів варто відзначити такі роботи як: Liu Z, Yang S, Sun B, Chang X, Zheng J, Li X. [5], Li Y, Xu H, Chien P-H [6], Chen L, Fan L-Z. [7], Hwang J-Y, Myung S-T, Sun Y-K. [8], Blomgren GE. [9], Placke T, Kloepsch R, Duehnen S, Winter M. [10], Liang Y, Zhang W, Wu D, Ni Q-Q, Zhang MQ [11], Zhang X-Q, Cheng X-B, Zhang Q [12], Guo W, Fu Y. [13] та інші.

$\mathrm{У}$ сучасній літературі не розглянуто питання формування принципів розширення функціональних механізмів портативних електронних пристроїв. Основна увага, науковців присвячена питанню вдосконалення розміру ПЕП, саме тому питання розгляду перспективних напрямків розширення функціональності портативних електронних пристроїв $\epsilon$ актуальним та потребує детального опрацювання.

Постановка завдання. Дослідити зарубіжний досвід формування перспективних напрямків розширення функціональності портативних електронних пристроїв.

Викладення основного матеріалу дослідження. У наш час багатий інформацією світ стає все більш портативним. 3 огляду на величезні вимоги до своєчасної та ефективної доставки глобальної інформації, для збору та передачі інформації потрібна портативна платформа обміну інформацією для реагування в режимі реального часу.

Електрохімічні системи накопичення енергії, особливо акумуляторні батареї, впродовж десятиліть широко використовуються як джерела енергії ПЕП і сприяють зростанню областей застосування ПЕП. Акумуляторні батареї ПЕП пройшли нікель-кадмієві (Ni-Cd), нікель-металеві гідриди (Ni-MH), літій-іонні (Li-ion) батареї тощо. Їх питома енергія та питома потужність істотно покращуються 3 часом. Однак нинішня технологія розробки акумуляторів не може повністю наздогнати стрімке зростання ПЕП. Сучасна технологія акумуляторних батарей для ПЕП виявила багато недоліків, тобто обмежену ємність накопичення енергії, короткий термін служби та високий рівень саморозряду, що стало головними недоліками для подальшого розвитку ПЕП. Наприклад, велике споживання багатофункціональних ПЕП вимагає систем накопичення енергії з більшою енергією, меншим об’ємом, меншою вагою та більшим часом експлуатації. 
Однак для сучасних батарей складно задовольнити постійно зростаючі вимоги електричного та електронного обладнання, що виникають. Тому раціональне проектування та виробництво нових акумуляторів було пріоритетним напрямком для майбутніх ПЕП.

Швидкий прогрес ПЕП неможливий без поступового вдосконалення технологій акумуляторних батарей. Первинні батареї вже використовувались як основне джерело енергії ПЕП протягом тривалого періоду. Однак значні успіхи акумуляторних батарей з вищою щільністю енергії та потужності помітно змінили ситуацію з початку 21 століття. В даний час акумуляторні батареї вже застосовуються в більшості ПЕП.

Закордонні виробники розробили і включили кілька різних типів акумуляторних батарей, включаючи свинцево-кислотні, Ni-Cd, Ni-MH та Li-ion акумулятори. Ці акумуляторні батареї часто приймають чотири типи форми, тобто монетні, циліндричні, призматичні та комірчасті елементи.

Завдання збільшення щільності енергії акумулятора зумовило весь прогрес технології роботи акумуляторів за останні два десятиліття. На сьогоднішній день щільність енергії батареї залишається основним критерієм вибору акумуляторної системи для ПЕП, що особливо важливо для ПЕП через обмежений простір та вагу, відведений для батарей у ПЕП. Однак досягнення у збільшенні щільності енергії акумулятора не встигають за темпом зростання потреб ПЕП. Незважаючи на те, що літій-іонні акумулятори мають найвищу щільність енергії серед різних акумуляторів, їх щільність енергії, коливаючись від 170 до $250 \mathrm{BT}^{\prime} \mathrm{\kappa}^{-1}$ або від 350 до $700 \mathrm{BT} \cdot$ год $\pi^{-1}$, все ще не в змозі впоратись із зростаючими потребами в накопиченні енергії, що виникають ПЕП. Отже, є загальносвітовим i нагальним бажанням ще більше збільшити щільність енергії акумуляторних батарей.

Оскільки питома ємність акумуляторів та робоча напруга визначають їх щільність енергії, підвищення цих двох параметрів було першочерговим завданням досліджень. Методи першої категорії спрямовані на оптимізацію існуючих акумуляторних батарей, включаючи їх електродні матеріали, електроліти, сепаратори, сполучні, струмоприймачі та технології виготовлення батарей (наприклад, збільшення щільності упаковки та масових відношень активних електродних матеріалів у зібраних батареях). Наприклад, графіт є загальним анодним матеріалом для комерційних літій-іонних акумуляторів завдяки своїй хорошій стабільності, чудовій провідності та високій кулонівській ефективності. Однак теоретична ємність Li-накопичувача графітових анодів становить лише 372 мАг $\Gamma^{-1}$. Багато інших матеріалів із більшою ємністю зберігання Li, таких як $\mathrm{Si}\left(4200\right.$ мАг $\left.\Gamma^{-1}\right), \mathrm{Sn}(994$ мАг $\left.\Gamma^{-1}\right), \mathrm{SnO}_{2}\left(782 \mathrm{мA} \Gamma^{-1}\right), \mathrm{Fe}_{2} \mathrm{O}_{3}\left(1007\right.$ мАг $\left.\Gamma^{-1}\right), \mathrm{MnO}_{2}\left(1232 \mathrm{мA} \Gamma^{-1}\right), \mathrm{Co}_{3} \mathrm{O}_{4}\left(890\right.$ мАг $\left.\Gamma^{-1}\right)$, i NiO (718 мАг $\left.\Gamma^{-1}\right)$, досліджені як нові анодні матеріали. Подібним чином традиційні катодні матеріали (наприклад, оксид кобальту $\mathrm{Li}$, фосфат заліза Li та оксид марганцю) можуть бути замінені матеріалами ємності (наприклад, багатошарові оксиди, багаті $\mathrm{Ni}$ та багатошарові оксиди, багаті Li) або матеріалами напруги (наприклад, оксиди поліаніону та шпінелі). Ці зусилля змогли значно покращити щільність енергії літій-іонних батарей, принаймні в багатьох лабораторних дослідженнях.

Методи другої категорії спрямовані на розробку нових акумуляторів. Існує припущення, що існуючі батареї, включаючи літій-іонні акумулятори, мають обмежений простір для подальшого вдосконалення. Прорив у збільшенні щільності енергії батареї вимагає розвитку нових електрохімічних реакцій. У цьому напрямку в останні роки інтенсивно застосовуються нові акумуляторні системи, включаючи металеві батареї Li, металеві сірчані батареї, металеві повітряні (або металево-кисневі) батареї, та батареї, що включають одновалентні (наприклад, $\mathrm{Na}$ i K) або багатовалентні (наприклад, $\mathrm{Mg}, \mathrm{Ca}, \mathrm{Zn}$ та $\mathrm{Al}$ ) елементи / катіони. Серед різних нових акумуляторних систем, Li-сірчані, Li-металеві та Li-кисневі батареї завоювали велику привабливість завдяки своїй винятково високій щільності енергії. Зокрема, Li-сірчані та Li-кисневі батареї мають теоретичну

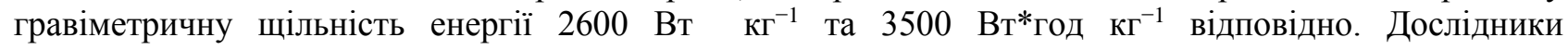
сподіваються, що вони можуть забезпечити практичну щільність енергії батареї від 2 до 5 в рази вище, ніж у сучасних літій-іонних акумуляторів.

Акумулятори становлять загрозу для безпеки, оскільки вони зберігають велику кількість хімічної енергії на невеликому просторі, i, отже, вони схильні до пожежі або вибухів при неправильній експлуатації. Батареї, що використовуються в ПЕП, особливо небезпечні для людини через їх характеристики. У всьому світі відбувалися численні інциденти, пов'язані з пожежами та вибухами акумуляторів, особливо із залученням мобільних телефонів, ноутбуків та електромобілів.

Наприклад, Федеральна авіаційна адміністрація США повідомила про понад 206 випадків пожежі / вибуху батареї з 1991 по 2020 роки. Проблеми з акумулятором Boeing 787 Dreamliner та Samsung Note 7 привернув увагу усього світу. Вкрай бажано максимально наголосити на безпеці для нових батарей, що використовуються в нових ПЕП. 
Причини пожежі / вибуху акумулятора різняться, що може включати коротке замикання, механічні пошкодження, перезарядку батареї або виробничі дефекти. Для підвищення безпеки батареї запропоновано численні методи. Ці методи можна розділити на зовнішні або і підходи внутрішнього захисту. Підходи зовнішнього захисту зазвичай використовують додаткові зовнішні пристрої. Наприклад, використання температурних датчиків і клапанів тиску для контролю батарей в умовах перегрівання або зловживання тиском. Ці технології $є$ відносно досконалими, які тут детально не розглядаються. Підходи внутрішнього захисту зосереджені на впровадженні іскробезпечних компонентів у різні компоненти акумуляторів. Спочатку до електролітів додають хімічні добавки. Ці хімічні добавки зазвичай містять вогнезахисні речовини, іонні рідини, відключення та окислювальновідновлювальні добавки. По-друге, деякі інші хімічні компоненти використовуються для досягнення стабільних інтерфейсів електрод / електроліт. По-третє, тверде тіло батареї на основі полімерних гелів або неорганічних електролітів також досліджувалось 3 наближенням внутрішнього захисту. Полімерні гелеві електроліти можуть покращити безпеку батареї, оскільки менше органічних розчинників використовується без витоків. Крім того, неорганічні тверді керамічні електроліти (наприклад, $\mathrm{Li}_{7} \mathrm{La}_{3} \mathrm{Zr}_{2} \mathrm{O}_{12}, \mathrm{Li}_{14} \mathrm{ZnGe}_{4} \mathrm{O}_{16}$ та $\mathrm{Li}_{3} \mathrm{XLa}_{2}$ /3-х $\mathrm{TiO}_{3}$ ) або склокерамічні електроліти привабливі тим, що вони негорючі, недорогі, не мають витоків і стійкі до високих температур. Механічна жорсткість твердих керамічних електролітів пригнічує утворення дендритів Li, що є основною причиною короткого замикання батареї. По-четверте, оптимізація сепараторів, струмоприймачів, анодних матеріалів та катодних матеріалів також може покращити безпеку батарей.

Слід зазначити, що ці внутрішні методи захисту частіше використовуються в літій-іонних батареях через високу реакційну здатність матеріалів, що використовуються в літій-іонних батареях. Загалом, літій-іонні акумулятори становлять більший ризик для безпеки в порівнянні з іншими акумуляторними батареями, що розглядаються в даній статті.

Батареї, що використовуються в ПЕП, повинні відповідати цільовим цінам для досягнення комерційного успіху. Літій-іонні акумулятори успішно домінують на сучасному ринку батарей ПЕП. Однак через їх високу вартість (зазвичай $300 \$$ кВт-год ${ }^{-1}$, тоді як $90 \$$ кВт-год- ${ }^{-1}$ для свинцевокислотних акумуляторів) було докладено багато зусиль для зменшення вартості літій-іонних батарей за рахунок конструкцій та синтезу матеріалів, виробництва та упаковки. Ці зусилля діляться на дві категорії. Перша категорія передбачає зниження вартості різних компонентів батареї (тобто катодів, анодів, електролітів, сепараторів, в'яжучих речовин та струмоприймачів) або зменшення виробничих витрат акумуляторів. Вартість матеріалів для батарей тісно пов'язана $з$ процесом їх синтезу і ціною на сировину. За останні десятиліття великі зусилля були спрямовані на розробку нових екологічно чистих шляхів синтезу акумуляторних матеріалів та вивчення стійких замінників акумуляторних матеріалів.

Друга категорія зосереджена на розробці більш дешевих батарей для заміни літій-іонних акумуляторів. Через обмежену доступність та нерівномірність розподілу Li у світі, альтернативні металево-іонні батареї, що використовують багаті землею металеві елементи, такі як Na-ion, Zn-ion, K-ion, Mg -іон та Al-iонні батареї. Наприклад, на Na припадає 2,64\% запасів земної кори, що на 4-5 порядків перевищує Li. Крім того, Na широко розподіляється і легко добувається, що призводить до зниження ціни. Подібні обставини можна виявити для Zn та інших елементів. Незважаючи на великі зусилля та значний прогрес, досягнутий у дослідницьких лабораторіях, багато питань доводиться долати, щоб ці нові акумуляторні системи стали конкурентоспроможною альтернативою літій-іонним акумуляторам.

Портативні електронні пристрої, особливо ті, що мають механічну гнучкість (наприклад, зсувні дисплеї), представляють новий напрямок для електронної промисловості. Крім того, вони можуть поєднуватися 3 мобільними датчиками (наприклад, розумним одягом), щоб зробити революцію в житті людини. Високі вимоги споживачів обумовлюють розвиток таких гнучких пристроїв. Деякі гнучкі засоби вже доступні на ринку, наприклад, FlexPai та Samsung Infinity Flex. Гнучкі акумуляторні батареї стали активною сферою досліджень протягом останніх кількох років, щоб задовольнити вимоги до накопичення енергії в цих гнучких пристроях.

На сьогоднішній день продемонстровано різні типи гнучких акумуляторів, включаючи гнучкі літій-іонні, літій-сірчані, літій-повітряні та Zn-повітряні батареї. Незважаючи на ці досягнення, серйозні технічні проблеми залишаються. Електрохімічні функції гнучких батарей зазвичай погіршуються при тривалих частих механічних деформаціях, наприклад, при згинанні, згортанні, скручуванні та інших режимах деформації. 3 високою ємністю, можливістю швидкого заряджання / 
розряджання та чудовою стабільністю на циклі, що може бути додатково поєднано $з$ гнучкими електролітами та сепараторами.

Висновки і перспективи подальших досліджень. У роботі розкрито зарубіжний досвід формування перспективних напрямків розширення функціональності портативних електронних пристроїв.

ПЕП $\epsilon$ важливими платформами для здійснення ефективного збору, обробки та розповсюдження інформації. Вони пережили стрімке зростання протягом попередніх трьох десятиліть. Ефективність цих ПЕП стає все більш чутливою до споживання енергії, що залежить від компонентів для накопичення енергії, тобто акумуляторів. Постійно зростаючі вимоги до високопродуктивних акумуляторів зумовлюють розвиток комерційних акумуляторних пристроїв від свинцево-кислотних до $\mathrm{NiCd}$, від $\mathrm{Ni}-\mathrm{MH}$ та до літій-іонних акумуляторів.

3 метою подальшого задоволення постійно високих вимог до акумуляторних батарей у ПЕП, значні зусилля у галузі досліджень у всьому світі були спрямовані на вдосконалення існуючих акумуляторних систем 3 використанням нових матеріалів, передових технологій та нових енергетичних хімічних сполук.

Поточна розвідка системи накопичення енергії дає змогу стабільно розвивати акумуляторну технологію з підвищеною питомою енергією, кращою безпекою та меншими витратами, особливо під впливом великих вимог ПЕП та електромобілів. Серед різних нових технологій акумуляторів Liбатареї на металевій основі, іонно-натрієві батареї, а також акумуляторні батареї 3 твердими електролітами $є$ перспективними системами накопичення енергії в майбутньому для заміни існуючих батарей. Ці наступні покоління вдосконалених акумуляторів сприятимуть розробці нових інформаційних пристроїв для постійного просування вперед.

3 розвитком технології акумуляторних батарей найближчим часом очікується все більше i більше багатофункціональних ПЕП. Тенденція розвитку ультрасучасних технологій акумуляторних батарей вимагає точного збігу між вимогами пристроїв та електрохімічними показниками процесу накопичення енергії, що також є давно переслідуваною метою індивідуального дизайну батарей для конкретних застосувань. Для реалізації цього питання дуже важливо встановити кращі сполучення між матеріалами, функціональними можливостями, програмами та їх новинками.

Список бібліографічного опису.

1. Король А. В. Перспективи використання мобільного навчання у ВНЗ України з європейським рівнем викладання / А. В. Король, Т. А. Кравцова, О. М. Муравйова // Економічна стратегія і перспективи розвитку сфери торгівлі та послуг. - 2016. - Вип. 1. - С. 271-280. - Режим доступу: http://nbuv.gov.ua/UJRN/esprstp_2016_1_29.

2. Черненко O.A. Перспективи розвитку мобільної комерції в Україні / Commercial Law / Комерційне право IUS PRIVATUM 2. 2018. - C. 29-34.

3. Гріччіна А. В. Можливості використання мобільних додатків для розвитку іншомовної мовленнєвої компетенції студентів / А. В. Гріччіна // Вісник Харківського національного автомобільно-дорожнього університету. - 2020. - Вип. 90. - С. 178-182. - Режим доступу: http://nbuv.gov.ua/UJRN/vhad_2020_90_26.

4. Будько В.І. Використання енергії сонячного випромінювання та вітру для зарядження електромобілів Рукопис. Дисертація на здобуття вченого ступеня доктора технічних наук за спеціальністю 05.14.08 «Перетворювання відновлюваних видів енергії» Національний технічний університет України «Київський політехнічний інститут ім. Ігоря Сікорського» МОН України, Інститут відновлюваної енергетики НАН України, Київ, 2019. - 302 с.

\section{References.}

1. Liu Z, Yang S, Sun B, Chang X, Zheng J, Li X. A peapod-like CoP@C nanostructure from phosphorization in a lowtemperature molten salt for high-performance lithium-ion batteries. Angew. Chem. Int. Ed. 2018;57:10187.

2. $\mathrm{Li} \mathrm{Y}, \mathrm{Xu} \mathrm{H}$, Chien P-H, et al. A perovskite electrolyte that is stable in moist air for lithium-ion batteries. Angew. Chem. Int. Ed. 2018;57:8587.

3. Chen L, Fan L-Z. Dendrite-free Li metal deposition in all-solidstate lithium sulfur batteries with polymer-in-salt polysiloxane electrolyte. Energy Storage Mater. 2018;15:37.

4. Hwang J-Y, Myung S-T, Sun Y-K. Sodium-ion batteries: Present and future. Chem. Soc. Rev. 2017;46:3529.

5. Blomgren GE. The development and future of lithium ion batteries. J. Electrochem. Soc. 2017;164:A5019.

6. Placke T, Kloepsch R, Duehnen S, Winter M. Lithium ion, lithium metal, and alternative rechargeable battery technologies: The odyssey for high energy density. J. Solid State Electrochem. 2017;21:1939.

7. Liang Y, Zhang W, Wu D, Ni Q-Q, Zhang MQ. Interface engineering of carbon-based nanocomposites for advanced electrochemical energy storage. Adv. Mater. Interfaces. 2018;5:1800430.

8. Zhang X-Q, Cheng X-B, Zhang Q. Advances in interfaces between Li metal anode and electrolyte. Adv. Mater. Interfaces. 2018;5:1701097.

9. Guo W, Fu Y. A perspective on energy densities of rechargeable Li-S batteries and alternative sulfur-based cathode materials. Energy Environ Mater. 2018;1:20. 